\title{
The Role of Transurethral Resection in Trimodal Therapy for Muscle-Invasive Bladder Cancer
}

\author{
Christopher M. Russell ${ }^{\mathrm{a}}$, Amir H. Lebastchi ${ }^{\mathrm{a}}$, Tudor Borza ${ }^{\mathrm{a}}$, Daniel E. Spratt ${ }^{\mathrm{b}}$ \\ and Todd M. Morgan ${ }^{\mathrm{a}, *}$ \\ ${ }^{a}$ Department of Urology, University of Michigan, Ann Arbor, MI, USA \\ ${ }^{\mathrm{b}}$ Department of Radiation Oncology, University of Michigan, Ann Arbor, MI, USA
}

\begin{abstract}
While radical cystectomy (RC) with pelvic lymph node dissection (PLND) represents the accepted gold standard for the treatment of muscle-invasive bladder cancer, this treatment approach is associated with significant morbidity. As such, bladder preservation strategies are often utilized in patients who are either deemed medically unfit due to significant comorbidities or whom decline management with RC and PLND secondary to its associated morbidity. In a select group of patients, meeting strict criteria, bladder preservation approaches may be employed with curative intent. Trimodal therapy, consisting of complete transurethral resection of bladder tumor (TURBT), chemotherapy, and radiation therapy has demonstrated durable oncologic control and long-term survival in a number of studies. The review presented here provides a description of trimodal therapy and the role of TURBT in bladder preservation for patients with muscle-invasive bladder cancer.
\end{abstract}

Keywords: Trimodal therapy, TMT, bladder cancer, transurethral resection, radiotherapy

\section{INTRODUCTION}

Radical cystectomy (RC) with pelvic lymph node dissection (PLND) has long represented the gold standard of treatment in patients with muscle-invasive bladder cancer (MIBC). RC and PLND allows for potentially definitive local oncologic control, and its utilization is supported by a large body of evidence $[1,2]$. Nevertheless, $\mathrm{RC}$ is associated with substantial morbidity, as 30-day complication and mortality rates can range from $31-51 \%$ and $1.5-2.7 \%$, respectively [3-5]. As such, bladder preservation strategies are often employed as an alternative treatment option.

\footnotetext{
*Correspondence to: Todd M. Morgan, Department of Urology, University of Michigan, 1500 E. Medical Center Drive, CCC 7308, Ann Arbor, MI 48109-2800, USA. Tel.: +1 734615 6662; Fax: +1 734647 9480; E-mail: tomorgan@med.umich.edu.
}

Bladder preserving approaches are generally utilized in two very different subsets of patients: a) those deemed medically unfit due to comorbidities or opting against RC with PLND, and b) those meeting strict criteria for curative intent. These criteria include urothelial histology, cT2 disease, complete transurethral resection of bladder tumor (TURBT) with no visible tumor remaining, and lack of hydronephrosis [6]. Single modality bladder preservation techniques, including isolated TURBT, radiotherapy (RT), or chemotherapy are widely acknowledged to result in inferior oncologic and survival outcomes when compared to RC [7-13]. However, trimodal therapy (TMT), consisting of complete TURBT, chemotherapy, and RT has demonstrated durable oncologic control and long-term survival in a number of studies, including two phase 3 randomized controlled trials (RCT) and a large 
pooled analysis [14-18]. TMT represents the most widely studied approach to bladder preservation, and its utilization has gained broader acceptance. Existing TMT series have identified a number of prognostic factors associated with long-term oncologic outcomes, with completion of maximal TURBT consistently representing the strongest predictor of success [16, 19-27]. It is important to note, however, that complete TURBT represents a subjective procedural assessment that is not amenable to control between providers or published series. The review presented here provides a detailed description of the role of TURBT in trimodal therapy and subsequent follow-up.

\section{TRIMODAL THERAPY AS A TREATMENT MODALITY FOR MIBC}

\section{Treatment Strategies}

There are two approaches to TMT that have been described in the literature; split-course (Fig. 1) and continuous-course regimens (Fig. 2). The split course approach was developed through the Radiation Therapy Oncology Group (RTOG) and consists of maximal TURBT followed by induction RT with concurrent chemotherapy and mid-course restaging TURBT/biopsy. Presence of invasive disease (T1 or greater) on this re-staging procedure necessitates immediate $\mathrm{RC}$ if cure is the intent. Those determined to have a complete response or recurrence limited to superficial (Ta or Tis) disease are then treated with a course of consolidation chemoand radiation therapy (chemo-RT) and followed with regular interval cystoscopy. Following consolidation chemo-RT, subsequent non-muscle invasive bladder cancer (NMIBC) recurrences are managed similarly to those with newly diagnosed NMIBC, with complete repeat TURBT with or without intravesical therapy. The largest institutional experience with split-course TMT comes out of the Massachusetts General Hospital (MGH), with numerous published series representative of distinct RTOG treatment protocols [19].

In continuous-course regimens, maximal TURBT is followed by chemo-RT and restaging TURBT/biopsy is delayed until 1-3 months following completion of chemo-RT regimens, allowing for adequate time for clinical response. Those determined to have a complete response based

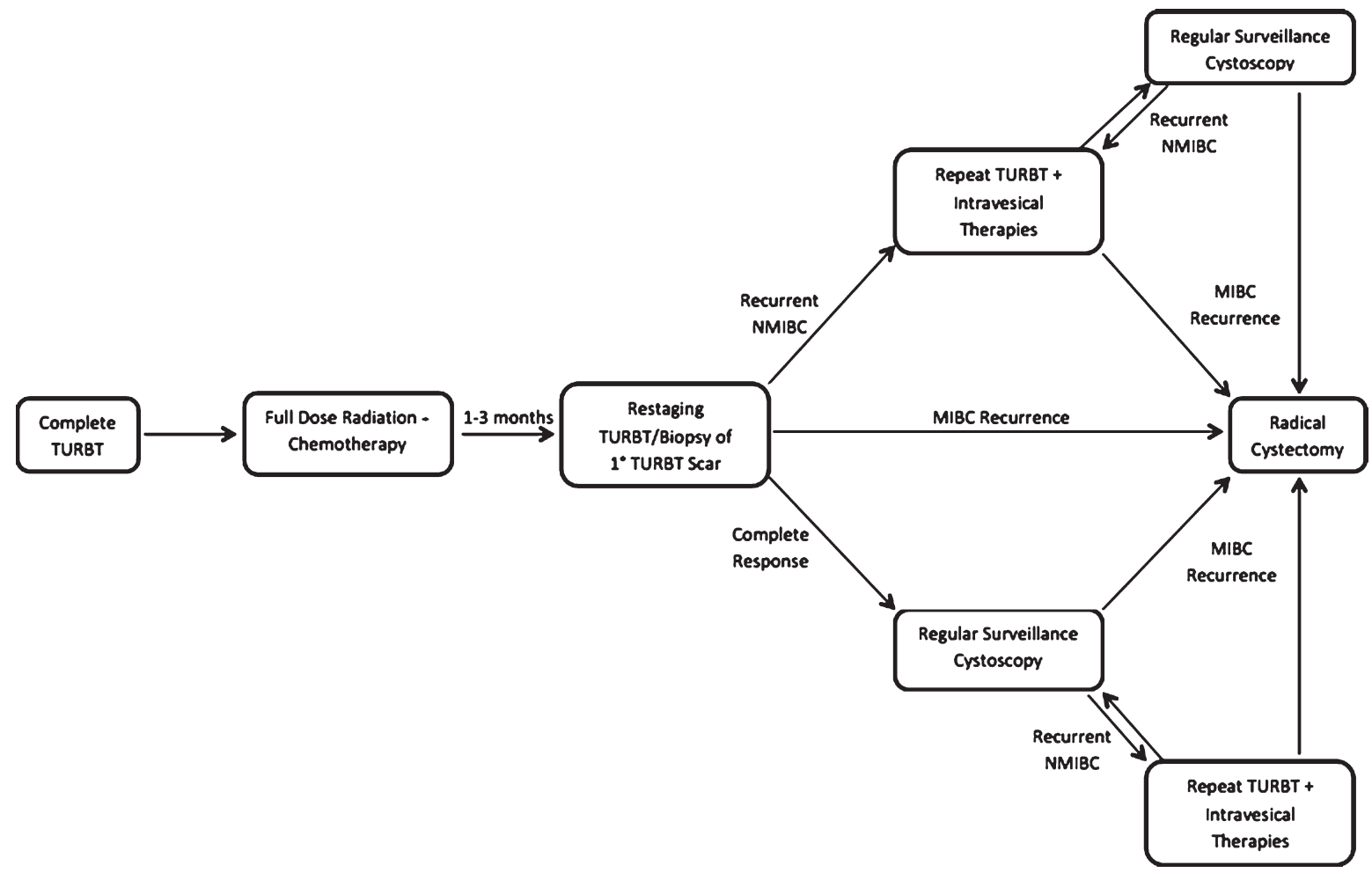

Fig. 1. Pictographic representation of split-course trimodal therapy regimen. 


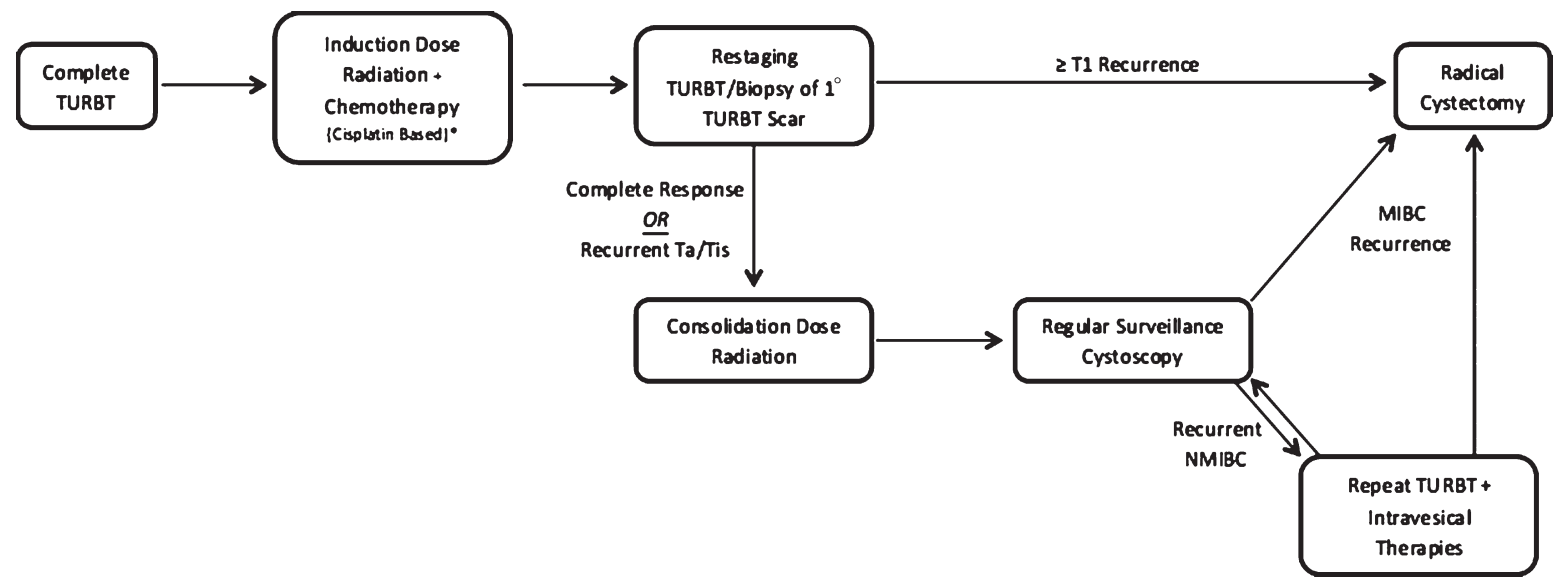

Fig. 2. Pictographic representation of continuous-course trimodal therapy regimen.

on a negative re-staging TURBT/biopsy are placed into a surveillance arm and are followed with regular interval cystoscopy. Again, patients with recurrent NMIBC are managed with repeat TURBT with or without intravesical therapy followed by interval surveillance cystoscopy. Recurrence of MIBC at any point is managed with salvage RC. This treatment approach has been validated by a number of longterm institutional series and prospective studies and represents an increasingly utilized TMT approach [14, 19, 28-30]. Currently no prospective studies exist comparing split and continuous regimens, and utilization is generally determined by institutional preference and experience. Additionally, the use of intravesical therapies, including Mitomycin C, Valrubicin, and BCG in conjunction with TMT has not yet been investigated. Any utilization of these agents would be based on evidence extrapolated from non-TMT series, and there is currently no defined role for intravesical therapy in the setting of TMT. A detailed summary of currently available continuous and split course TMT series is provided in Table 1.

\section{Impact of TURBT on TMT Response}

TMT is primarily employed for patients with good performance status and who elect to attempt bladder preservation with $\mathrm{RC}$ implemented only as a salvage option. Predictors of treatment response remain a critical need, however, as TMT non-responders have a 20-40\% lower 5-year cancer specific survival (CSS) following salvage $\mathrm{RC}$ compared to those undergoing immediate RC [16, 19-28, 31-34]. That being said, maximal TURBT (visually complete resection of the tumor) is the strongest predictor of both oncologic control and TMT success, with a documented 20\% increase in complete response and long-term bladder preservation in those receiving complete TURBT [19]. The therapeutic benefit of TURBT is likely secondary to the direct resection of all readily identifiable muscle-invasive disease but also may be a surrogate for disease aggressiveness. While, the presence of previously unidentified tumor on restaging TURBT signifies disease that is more likely to fail TMT, the ability to perform a complete re-resection allows for optimization of RT, thus increasing the likelihood of TMT success within this subset of patients. Of note, the absence of maximal TURBT was an exclusion criteria for several TMT series, further signifying the importance of this factor [31, 32, 35].

In addition to incomplete TURBT, several other variables predictive of poor therapeutic response have been identified. Hydronephrosis has been an exclusion criteria for RTOG protocols since 1993, as patients without evidence of ureteral obstruction have demonstrated a response rate $\geq 1.5$ times that of patients with hydronephrosis [24, 33]. Multifocality, while not shown to be significantly associated with response rates or survival, has been associated with higher risk for local relapse and generally represents an exclusion criteria for all previous TMT trials, and bladder preservation is generally not recommended in this population [28, 34]. Previous series of RT monotherapy also demonstrated poor response rates in patients with T4 disease and CIS, and given that RT represents an integral component of TMT, it has been the general consensus that these patients remain poor candidates even with a multi-modal approach [36]. Additionally, high-risk histologic features associated 
Table 1

Summary of published continuous and split course TMT series

\begin{tabular}{|c|c|c|c|c|c|c|c|c|c|c|c|}
\hline & Study Design & $\begin{array}{l}\text { Split/ } \\
\text { Continuous } \\
\text { Course } \\
\end{array}$ & $\begin{array}{l}\text { Follow-up } \\
\text { (months) }\end{array}$ & $N$ & $\begin{array}{l}\text { Chemotherapy } \\
\text { Regimen }\end{array}$ & RT Dose & $\begin{array}{l}\text { Neoadjuvant/ } \\
\text { Adjuvant } \\
\text { Regimen } \\
\end{array}$ & $\begin{array}{l}\text { Complete } \\
\text { Response } \\
\text { Rate } \\
\end{array}$ & $\begin{array}{l}\text { Salvage } \\
\text { RC Rate }\end{array}$ & CSS & OS \\
\hline $\begin{array}{r}\text { James et al., } \\
2012[14]\end{array}$ & $\begin{array}{c}\text { Prospective, } \\
\text { Phase III }\end{array}$ & Continuous & 69.9 & 182 & $\begin{array}{l}\text { 5-FU and } \\
\quad \text { Mitomycin } \mathrm{C} \times 2\end{array}$ & 55 or $64 \mathrm{~Gy}$ & - & - & $11.4 \%$ & - & $48 \%(5 \mathrm{yr})$ \\
\hline $\begin{array}{l}\text { Tunio et al., } \\
2012[15]\end{array}$ & $\begin{array}{l}\text { Prospective } \\
\text { Phase III }\end{array}$ & Continuous & 60.0 & 200 & Cisplatin [Weekly] & $65 \mathrm{~Gy}$ & - & $93 \%$ & - & - & $52 \%(5 \mathrm{yr})$ \\
\hline $\begin{array}{l}\text { Zapatero et al., } \\
2012[31]\end{array}$ & Retrospective & Split & 60.0 & 39 & $\begin{array}{l}\text { Cisplatin } \\
\quad \text { (Paclitaxel: } n=5)\end{array}$ & $64.8 \mathrm{~Gy}$ & - & $80 \%$ & $33 \%$ & $82 \%(5 \mathrm{yr})$ & $73 \%(5 \mathrm{yr})$ \\
\hline \multirow[t]{2}{*}{$\begin{array}{l}\text { Efstathiou } \\
\text { et al., } 2012 \\
\text { [19] }\end{array}$} & Retrospective & Split & 92.4 & 348 & Various & Various & $\begin{array}{l}\text { Various Neoadjuvant } \\
\text { and Adjuvant } \\
\text { Regimens }\end{array}$ & $78 \%$ & $29 \%$ & $5 \mathrm{yr}-64 \%$ & $5 \mathrm{yr}-52 \%$ \\
\hline & & & & & & & & & & $\begin{array}{l}10 \mathrm{yr}-59 \% \\
15 \mathrm{yr}-57 \%\end{array}$ & $\begin{array}{l}10 \mathrm{yr}-35 \% \\
15 \mathrm{yr}-22 \%\end{array}$ \\
\hline $\begin{array}{l}\text { Lagrange et al., } \\
2011 \text { [73] }\end{array}$ & $\begin{array}{l}\text { Prospective } \\
\text { Phase II }\end{array}$ & Split & 96.0 & 51 & $\begin{array}{l}\text { Cisplatin and } \\
5-\mathrm{FU} \times 3\end{array}$ & $63 \mathrm{~Gy}$ & - & - & $33.3 \%$ & - & $8 \mathrm{yr}-36 \%$ \\
\hline $\begin{array}{l}\text { Choudhury } \\
\text { et al., } 2011 \\
\text { [72] }\end{array}$ & $\begin{array}{l}\text { Prospective } \\
\text { Phase II }\end{array}$ & Continuous & 36.0 & 50 & $\begin{array}{l}\text { Gemcitabine } \\
\text { [Weekly] }\end{array}$ & $52.5 \mathrm{~Gy}$ & - & $82 \%$ & $14 \%$ & $3 \mathrm{yr}-82 \%$ & $3 \mathrm{yr}-75 \%$ \\
\hline $\begin{array}{l}\text { Krause et al., } \\
2011 \text { [30] }\end{array}$ & Retrospective & Split & 71.5 & 473 & Various & $\begin{array}{l}\text { Various (RT only: } \\
\quad n=126 \text { ) }\end{array}$ & - & $70.4 \%$ & - & $\begin{array}{r}5 \mathrm{yr}-78 \% \\
-\end{array}$ & $\begin{array}{l}5 \mathrm{yr}-65 \% \\
5 \mathrm{yr}-49 \%\end{array}$ \\
\hline $\begin{array}{r}\text { Sabaa et al., } \\
2010[22]\end{array}$ & Retrospective & Split & 47.0 & 104 & Cisplatin $\times 2$ & $60-65$ Gy & $\begin{array}{l}\text { Neoadjuvant } \\
\text { Gemcitabine and } \\
\text { Cisplatin } \times 3\end{array}$ & $78.8 \%$ & $16.7 \%$ & $5 \mathrm{yr}-76 \%$ & $\begin{array}{r}10 \mathrm{yr}-30 \% \\
5 \mathrm{yr}-68 \%\end{array}$ \\
\hline $\begin{array}{l}\text { Aboziada et al., } \\
2009 \text { [74] }\end{array}$ & Retrospective & Split & 18.0 & 50 & Cisplatin [Weekly] & $66 \mathrm{~Gy}$ & - & $60 \%$ & $28 \%$ & $1.5 \mathrm{yr}-84 \%$ & $1.5 \mathrm{yr}-100 \%$ \\
\hline $\begin{array}{c}\text { Kaufman et al., } \\
2009 \text { [69] }\end{array}$ & $\begin{array}{l}\text { Prospective } \\
\text { Phase } I+\text { II }\end{array}$ & Split & 49.4 & 80 & $\begin{array}{l}\text { Cisplatin [Weekly] } \\
\quad+\text { Paclitaxel } \times 5\end{array}$ & $64.3 \mathrm{~Gy}$ & $\begin{array}{l}\text { Adjuvant } \\
\text { Cisplatin and } \\
\text { Gemcitabine } \times 4\end{array}$ & $81 \%$ & $12.5 \%$ & $5 \mathrm{yr}-71 \%$ & $5 \mathrm{yr}-56 \%$ \\
\hline $\begin{array}{l}\text { Perdona et al., } \\
2008 \text { [21] }\end{array}$ & Retrospective & Continuous & 66.0 & 78 & $\begin{array}{l}\text { Cisplatin } \\
\quad \text { (Carboplatin: } \\
n=25)\end{array}$ & 65 Gy & $\begin{array}{c}\text { Neoadjuvant } \\
\mathrm{CMV} \times 2\end{array}$ & $85.7 \%$ & $20.2 \%$ & $5 \mathrm{yr}-79 \%$ & $5 \mathrm{yr}-72 \%$ \\
\hline $\begin{array}{l}\text { Weiss et al., } \\
2007[65]\end{array}$ & Retrospective & Continuous & 27.0 & 112 & $\begin{array}{l}\text { Cisplatin and } \\
5 \text {-FU } \times 2\end{array}$ & $55.8-59.4$ Gy & - & $88 \%$ & $17 \%$ & $5 \mathrm{yr}-82 \%$ & $5 \mathrm{yr}-74 \%$ \\
\hline $\begin{array}{l}\text { Gogna et al., } \\
2006[70]\end{array}$ & $\begin{array}{l}\text { Prospective } \\
\text { Phase II }\end{array}$ & Continuous & 23.0 & 113 & Cisplatin [Weekly] & 63-64 Gy & - & $70 \%$ & $15 \%$ & $5 \mathrm{yr}-50 \%$ & \\
\hline $\begin{array}{l}\text { Cobo et al., } \\
2006[27]\end{array}$ & Retrospective & Split & 69.4 & 29 & Cisplatin $\times 2$ & $64.8 \mathrm{~Gy}$ & $\begin{array}{l}\text { Neoadjuvant } \\
\text { CMV } \times 2 \text { or } \\
\text { Gemcitabine and } \\
\text { Cisplatin }\end{array}$ & $86 \%$ & $24.1 \%$ & - & $6 \mathrm{yr}-72 \%$ \\
\hline
\end{tabular}




\begin{tabular}{|c|c|c|c|c|c|c|c|c|c|c|c|}
\hline $\begin{array}{l}\text { Kragelj et al., } \\
2005[61]\end{array}$ & $\begin{array}{l}\text { Prospective } \\
\text { Phase II }\end{array}$ & Continuous & 123.6 & 84 & $\begin{array}{r}\text { Vinblastine } \\
\text { [Weekly] }\end{array}$ & 63.8-64 Gy & - & $78 \%$ & $8.3 \%$ & $9 \mathrm{yr}-51 \%$ & $9 \mathrm{yr}-25 \%$ \\
\hline $\begin{array}{l}\text { Peyromaure } \\
\text { et al., } 2004 \\
\text { [32] }\end{array}$ & Retrospective & Split & 36.3 & 43 & $\begin{array}{l}\text { Cisplatin and } \\
5-\mathrm{FU} \times 2\end{array}$ & $24 \mathrm{~Gy}$ & - & $74.4 \%$ & $25.6 \%$ & $3 \mathrm{yr}-75 \%$ & - \\
\hline $\begin{array}{l}\text { Hussain et al., } \\
2004 \text { [77] }\end{array}$ & $\begin{array}{l}\text { Prospective } \\
\text { Phase } I+\text { II }\end{array}$ & Continuous & 50.7 & 41 & $\begin{array}{l}\text { Mitomycin } \mathrm{C} \text { and } 5 \\
\mathrm{FU} \times 2\end{array}$ & $55 \mathrm{~Gy}$ & - & $71 \%$ & $19.5 \%$ & $\begin{array}{l}5 \mathrm{yr}-60 \% \\
2 \mathrm{yr}-68 \%\end{array}$ & $2 \mathrm{yr}-49 \%$ \\
\hline $\begin{array}{l}\text { Danesi et al., } \\
2004 \text { [20] }\end{array}$ & Retrospective & Continuous & 82.2 & 77 & Cisplatin and 5-FU & $69 \mathrm{~Gy}$ & $\begin{array}{c}\text { Neoadjuvant } \\
\mathrm{CMV} \times 2\end{array}$ & $80.5 \%$ & $22.1 \%$ & $5 \mathrm{yr}-75 \%$ & $\begin{array}{l}5 \mathrm{yr}-36 \% \\
5 \mathrm{yr}-59 \%\end{array}$ \\
\hline $\begin{array}{l}\text { Hagan et al., } \\
2003[67]\end{array}$ & $\begin{array}{l}\text { Prospective } \\
\text { Phase } I+\text { II }\end{array}$ & Split & 26.0 & 47 & Cisplatin [Weekly] & $64.8 \mathrm{~Gy}$ & Adjuvant $\mathrm{CMV} \times 3$ & $74 \%$ & $25.5 \%$ & $\begin{array}{c}10 \mathrm{yr}-73 \% \\
-\end{array}$ & $\begin{array}{r}10 \mathrm{yr}-55 \% \\
3 \mathrm{yr}-61 \%\end{array}$ \\
\hline $\begin{array}{l}\text { Rödel et al., } \\
2002 \text { [28] }\end{array}$ & Retrospective & Continuous & 60.0 & 415 & Various & $\begin{array}{r}45-69.4 \mathrm{~Gy}(\mathrm{RT} \\
\text { alone: } n=126)\end{array}$ & - & $72 \%$ & $20 \%$ & $5 \mathrm{yr}-56 \%$ & $5 \mathrm{yr}-51 \%$ \\
\hline $\begin{array}{l}\text { Kaufman et al., } \\
2000 \text { [78] }\end{array}$ & $\begin{array}{l}\text { Prospective } \\
\text { Phase } I+\text { II }\end{array}$ & Split & 29.0 & 34 & $\begin{array}{l}\text { Cisplatin and } \\
5-\mathrm{FU} \times 4\end{array}$ & $44 \mathrm{~Gy}$ & - & $67 \%$ & $29.4 \%$ & $\begin{array}{r}10 \mathrm{yr}-42 \% \\
3 \mathrm{yr}-83 \%\end{array}$ & $10 \mathrm{yr}-31 \%$ \\
\hline $\begin{array}{l}\text { Arias et al., } \\
2000[23]\end{array}$ & Retrospective & Split & 73.0 & 50 & Cisplatin $\times 1$ & $65 \mathrm{~Gy}$ & $\begin{array}{l}\text { Neoadjuvant } \\
\text { M-VAC } \times 2\end{array}$ & $68 \%$ & $26 \%$ & - & $5 \mathrm{yr}-48 \%$ \\
\hline $\begin{array}{l}\text { Shipley et al., } \\
1998 \text { [16] }\end{array}$ & $\begin{array}{l}\text { Prospective } \\
\text { Phase III (Arm } \\
\text { 1: No } \\
\text { Neoadjuvant } \\
\text { Therapy) }\end{array}$ & Split & 60.0 & 62 & Cisplatin $\times 3$ & $64.8 \mathrm{~Gy}$ & - & $60 \%$ & $25.8 \%$ & - & $5 \mathrm{yr}-49 \%$ \\
\hline $\begin{array}{l}\text { Shipley et al., } \\
1998 \text { [16] }\end{array}$ & $\begin{array}{l}\text { Prospective } \\
\text { Phase III (Arm } \\
\text { 2: With } \\
\text { Neoadjuvant } \\
\text { Therapy) }\end{array}$ & Split & 60.0 & 61 & Cisplatin $\times 3$ & 64.8 & $\begin{array}{l}\text { Neoadjuvant } \\
\mathrm{CMV} \times 2\end{array}$ & $72.5 \%$ & $17 \%$ & - & $5 \mathrm{yr}-48 \%$ \\
\hline $\begin{array}{l}\text { Kachnic et al., } \\
1997 \text { [24] }\end{array}$ & Retrospective & Split & 52.8 & 106 & Cisplatin $\times 3$ & $64.8 \mathrm{~Gy}$ & $\begin{array}{c}\text { Neoadjuvant } \\
\mathrm{CMV} \times 2\end{array}$ & $80 \%$ & $21.7 \%$ & $5 \mathrm{yr}-60 \%$ & $5 \mathrm{yr}-52 \%$ \\
\hline $\begin{array}{r}\text { Fellin et al., } \\
1997 \text { [26] }\end{array}$ & $\begin{array}{l}\text { Prospective } \\
\text { Phase II }\end{array}$ & Split & 46.0 & 56 & Cisplatin & $64 \mathrm{~Gy}$ & $\begin{array}{l}\text { Neoadjuvant } \\
\mathrm{CMV} \times 2\end{array}$ & $50 \%$ & $46.4 \%$ & $5 \mathrm{yr}-59 \%$ & $5 \mathrm{yr}-54 \%$ \\
\hline $\begin{array}{r}\text { Tester et al., } \\
1996[25]\end{array}$ & $\begin{array}{l}\text { Prospective } \\
\text { Phase II }\end{array}$ & Split & 52.8 & 91 & Cisplatin $\times 3$ & $64.8 \mathrm{~Gy}$ & $\begin{array}{c}\text { Neoadjuvant } \\
\mathrm{CMV} \times 2\end{array}$ & $75 \%$ & $39.5 \%$ & - & $4 y r-62 \%$ \\
\hline $\begin{array}{c}\text { Housset et al., } \\
1993 \text { [17] }\end{array}$ & $\begin{array}{l}\text { Prospective } \\
\text { Phase III }\end{array}$ & Split & 27.0 & 54 & $\begin{array}{l}\text { Cisplatin and } \\
5-\mathrm{FU} \times 4\end{array}$ & $44 \mathrm{~Gy}$ & - & $74 \%$ & - & $3 \mathrm{yr}-62 \%$ & $3 \mathrm{yr}-59 \%$ \\
\hline $\begin{array}{r}\text { Tester et al., } \\
1993 \text { [75] }\end{array}$ & $\begin{array}{l}\text { Prospective } \\
\text { Phase III }\end{array}$ & Split & 36.0 & 48 & Cisplatin $\times 3$ & $64 \mathrm{~Gy}$ & - & $66 \%$ & $20.8 \%$ & - & $3 y r-64 \%$ \\
\hline $\begin{array}{l}\text { Russell et al., } \\
1990[76]\end{array}$ & $\begin{array}{l}\text { Prospective } \\
\text { Phase II }\end{array}$ & Split & 18.0 & 34 & 5-FU & $60 \mathrm{~Gy}$ & - & $81 \%$ & $29.4 \%$ & - & $4 y r-64 \%$ \\
\hline
\end{tabular}

RT=Radiation Therapy; RC=Radical Cystectomy; CSS=Cancer Specific Survival; OS=Overall Survival; 5-FU=5-Fluorouracil; CMV=Cisplatin, Vinblastine, Methotrexate; M$\mathrm{VAC}=$ Methotrexate, Cisplatin, Adriamycin, Vinblastine; $\mathrm{yr}=$ Year. 
with decreased overall therapeutic success following RC, including LVI, variant histology, and tumor grade, are likely prognostic in TMT $[37,38]$.

\section{TECHNIQUES FOR PERFORMING MAXIMAL TRANSURETHERAL RESECTION}

Transurethral resection of bladder tumor (TURBT) is one of the most commonly performed urologic procedures, and it is essential for adequately diagnosing and treating bladder tumors. Multiple established guidelines for both NMIBC and MIBC emphasize the importance of ensuring complete resection of all visible tumors and including detrusor muscle in the resection specimen [39-44]. Complete resection is associated with lower recurrence rates following initial TURBT in patients with non-muscle-invasive disease, and it is associated with improved long term oncologic outcomes in patients undergoing TMT. Despite these recommendations, multiple studies have reported residual cancer in 30-70\% of patients on repeat TURBT [45, 46]. Surgical technique, operator experience, and tumor size/location have all been shown to impact the quality and completeness of resection $[47,48]$. There are a number of key preoperative and intraoperative factors that should be considered in order to optimize TURBT outcomes.

\section{Preoperative considerations}

Key aspects of the patient history include tobacco use, prior history of bladder cancer, previous endoscopic surgical management, and history of intravesical therapy. During office-based cystoscopy, the exact location, size, number and appearance of the tumor or tumors should be well-documented. Photos or schematic diagrams may be uploaded into the electronic medical record to help document these findings. Preparation for surgery should include routine laboratory evaluation, typically a hematocrit/hemoglobin, electrolytes, and creatinine, as well as a urinalysis or urine culture to evaluate for a urinary tract infection.

There are also key anesthetic considerations that should be addressed in advance of TURBT. General anesthesia with complete neuromuscular blockade is often recommended, as it decreases the likelihood of an obturator reflex and subsequent bladder perforation during TURBT. Alternatively, spinal anesthesia can be utilized and allows for maximal paralysis and bladder relaxation during the surgical procedure with a documented $96 \%$ successful obturator reflex inhibition rate in one series [49]. Transurethral or ultrasound-guided injection of the obturator nerve has also been reported to be an effective method of adductor and obturator reflex blockade, and could be considered in patients in whom systemic neuromuscular blockade may be contraindicated [49, 50]. According to the AUA Best Practice Policy Statement on urologic surgery antimicrobial prophylaxis, patients should receive antimicrobial prophylaxis with a fluoroquinolone or sulfamethoxazole-trimethoprim. Alternatively, a 1st/2nd generation cephalosporin, aminoglycoside with or without ampicillin or amoxicillin/clavulanate may be used [51].

\section{Intraoperative considerations}

To begin the procedure, a systematic approach is critical and begins with a thorough pancystoscopy. This should be completed with the bladder volume maintained at approximately half-capacity in order to avoid over-distension and improve visualization. Again, the exact location of all identified tumors should be documented in order to facilitate appropriate surveillance, especially in lesions located in areas that may be difficult to visualize [52].

While small papillary lesions may be removed with either cold cup biopsy forceps or loop electrocautery, larger bladder tumors should be removed systematically with the loop electrocautery. An advantage of the cold cup biopsy technique for small lesions is the avoidance of cautery artifact, improving the pathologist's ability to analyze the specimen. When using electrocautery, either a monopolar or bipolar generator may be utilized, as these have been shown to be equally effective and safe $[53,54]$. While $T U R$ syndrome from absorption of hypotonic solutions is more commonly associated with prostate resection for benign prostatic hyperplasia, it can rarely occur following TURBT of large bladder tumors. Bipolar technology allows for the use of nonconductive isotonic irrigation fluids, substantially diminishing the risk of TUR syndrome. Furthermore, by using reduced power settings with bipolar instruments, the risk of triggering an obturator reflex can be decreased without a compromise in procedural efficacy.

TURBT of large bladder tumors can be a challenging procedure, and adherence to key principles is critical in order to provide optimal staging and maximize the chances for complete resection while 
maintaining patient safety. Great care needs to be taken to visualize the normal urothelium adjacent to the tumor in order to avoid perforation, and certainly the risk of complications, including perforation and post-operative hematuria, is greater with more extensive resections. Whenever feasible, resection should be initiated at the tumor edge, carried down to the detrusor muscle, and then carried systematically across the tumor. Resection of the detrusor muscle is imperative, and care should be taken to limit cautery artifact during resection [55]. When resecting large tumors, a separate specimen from the deep margin of resection containing muscularis propria should be included to facilitate accurate pathologic staging [52]. Very large tumors should be resected piecemeal prior to resecting the stalk of the tumor in order to avoid difficulties evacuating the tumor pieces from the resectoscope. If resection of the ureteral orifice is required, coagulation current around the orifice should be avoided, and it should be carefully examined at the end of the procedure to ensure efflux of urine.

\section{RECENT ADVANCES}

\section{Hexyl-aminolevulinate blue light cystoscopy (HAL-BLC)}

HAL-BLC has in recent years emerged as an important adjunct to white-light cystoscopy (WLC), to improve completeness and quality of resection [56]. HAL-BLC facilitates detection of additional lesions compared to WLC and is associated with reduced rates of recurrence [57-59]. HAL-BLC works through the photodynamic property of hexaminolevulinate (HAL) (Hexvix ${ }^{\circledR}$, Cysview $^{\circledR}$, Photocure ${ }^{\circledR}$ ), which is preferentially taken up by neoplastic cells. HAL was approved by the United States Food and Drug Administration (FDA) in 2010 to be used as an adjunct to WLC for the detection of NMIBC in select patients with known lesions identified on prior cystoscopy. 5-aminolevulinic acid (5-ALA) is another well-investigated compound with photodynamic properties, but which has not yet been approved by the FDA for routine clinical use. [59]

A large body of evidence supports the utility of HAL-BLC at the time of TURBT. Burger and colleagues demonstrated in a large meta-analysis of over 1,345 patients with NMIBC that the use of HAL-BLC as an adjunct to WLC significantly improved the detection rate of Ta tumors $(14.7 \%$ absolute increase, $p<0.001)$ and CIS $(40.8 \%$ absolute increase, $p<0.001$ ) [58]. Additionally, using HAL and blue light cystoscopy led to a statistically significant reduction in recurrence rates up to 12 months after resection (34.5\% vs $45.4 \% ; P=0.006)$. Patients undergoing HAL blue light cystoscopy receive $50 \mathrm{ml}$ of reconstituted solution instilled into an empty bladder via urethral catheter one hour prior to TURBT [47]. While the utilization of this technology has not been specifically studied in the setting of TMT, its incorporation could result in improved recognition of tumor multifocality and CIS, facilitating both complete resection and improved patient selection for TMT.

\section{TRANSURETHRAL RESECTION AS A COMPONENT OF TMT}

Completion of maximal debulking TURBT represents an important prognostic factor in patients undergoing TMT, yet its actual impact on survival is more difficult to assess. As previously discussed, maximal TURBT is associated with a $20 \%$ increase in TMT complete response and long-term bladder preservation rates [19]. The complete resection of all macroscopic elements at primary TURBT results in an optimized environment for chemo-RT to treat residual microscopic components, subsequently resulting in improved initial and long-term response rates. In those patients found to have residual disease at the time of interval TURBT, bladder preservation rates are significantly lower. However, in those receiving split-course regimens with recurrent Ta or Tis disease, repeat TURBT continues to play an important role, as it again allows for optimization of consolidation chemo-RT regimens [19].

In order to better understand the impact of maximal TURBT as a component of TMT, each treatment modality can be assessed separately. For context, 5year overall survival (OS) and CSS in patients treated with TMT ranges from $36-74 \%$ and $50-82 \%$, respectively [16, 19-28, 31-34]. This range likely stems from varying RTOG protocols, inclusion/exclusion criteria, follow-up durations, and study designs. Pooled analyses of TMT completed under various RTOG protocols have reported 5-year CSS of $60-65 \%[19,33]$.

There is a relative paucity of literature describing TURBT monotherapy for MIBC; however, durable bladder preservation has been reported in highly selected patients with small MIBC tumors. In one 
retrospective series, patients found to have no MIBC at repeat TURBT demonstrated a bladder preservation and overall survival rate of $57 \%$ and $76 \%$, respectively [8]. In another prospective series, Solsona and colleagues reported a 10-year CSS rate of $80 \%$ and 10-year progression free survival (PFS) rate of $65 \%$ [9]. Strict inclusion criteria were used in these studies, with only $11-35 \%$ of patients found to be eligible for definitive TURBT [8, 13]. Additionally, tumor recurrence and salvage cystectomy rates among this subset of patients is as high as $56 \%$ and $30 \%$, respectively $[8,13]$. The role of TURBT monotherapy in MIBC is thus limited, however its potential to effectively cure MIBC in a subset of patients is indicative of the potential impact of this modality as a component of TMT.

While RT alone was formerly utilized in the management of MIBC, isolated RT results in inferior 5 -year OS rates ranging from $26-35 \%[14,60]$. RT monotherapy is therefore now restricted to patients deemed unfit for surgery and chemotherapy. There are no data regarding the use of isolated chemotherapy in the management of MIBC, however in bladder preservation regimens, chemo-RT is widely favored over RT alone. Although limited data exists directly comparing these entities, a multicenter, phase 3 trial comparing isolated chemotherapy and chemo-RT for MIBC demonstrated improved 2-year PFS (67\% vs. $54 \%$, HR $0.68 ; p=0.03)$ and 5 -year OS $(48 \%$ vs. $35 \%$, HR $0.82 ; p=0.16$ ) rates in patients receiving chemo-RT as compared to RT alone [14].

While complete TURBT imparts a significant survival benefit, as evidenced by the efficacy of TURBT monotherapy, the ability of chemo-RT regimens to further reduce disease burden through the elimination of residual microscopic disease is a key component of TMT regimens and is indicative of the interdependence of these treatment modalities.

\section{THE ROLE OF NEOADJUVANT CHEMOTHERAPY PRIOR TO TURBT IN TMT}

While the oncologic benefit of neoadjuvant chemotherapy prior to RC in patients with MIBC is clear, this relationship may not hold true for patients undergoing bladder preservation with TMT. Several prospective and retrospective studies have investigated the efficacy of neoadjuvant chemotherapy in the setting of TMT. RTOG 89-03 represents the first large randomized trial directly comparing a standard TMT protocol with and without neoadjuvant cisplatin, methotrexate, and vinblastine (CMV) [61]. This study was terminated early due to high rates of severe toxicities, with only $64 \%$ of included patients completing their specified treatment regimen. Additionally, no significant difference was noted in complete response, metastasis-free survival, or overall survival between the two study arms. Several other series have also reported an increased incidence of adverse events associated with neoadjuvant cisplatin-based chemotherapy regimens, with overall completion rates ranging from $68-93 \%$ [25, $35,62,63]$. In agreement with these series, a review of the MGH institutional experience also failed to demonstrate a survival benefit associated with neoadjuvant chemotherapy in the setting of TMT $[19,33]$.

\section{THE ROLE OF TURBT IN TMT SURVEILLANCE}

Following completion of TMT, surveillance is crucial in light of the high recurrence risk. A standardized follow-up regimen does not currently exist for TMT responders, and surveillance protocols are widely provider dependent. The general recommendation from those with longstanding experience with TMT is for vigilant follow-up with cystoscopy and crosssectional imaging consisting of CT or MRI, with immediate salvage RC offered at the first sign of invasive disease recurrence. There is no consensus as to the frequency of post-TMT surveillance cystoscopy, however many providers follow standard high-risk NMIBC protocols with cystoscopy performed approximately every 3 months for the first 2 years, every 6 months for the next 2 years, and annually thereafter. Urine cytology should be collected with each cystoscopic evaluation and GU imaging should be performed annually.

The majority of TMT trials also advocate for repeat biopsy or re-resection of the original TURBT resection site at first surveillance cystoscopy, which is routinely completed 8-12 weeks following the completion of chemo-RT. Routine cold-cup biopsy at interval follow-up is not necessary but may be performed as deemed appropriate. Additionally, some recommend routine bi-manual examination due to the potential for MIBC recurrence deep to the original TURBT scar. Given the subjective nature of cystoscopy and lack of standardized documentation of precise examination findings, the urologist performing the original TURBT for TMT should 
ideally perform interval follow-up cystoscopies as well. The majority of TMT trials with a long duration of follow-up describe a flattening of the CSS curve at 5 years, similar to that observed with standard $\mathrm{RC}$, and indicating long-term durability for patients who respond to TMT [19]. Late recurrences can occur, however, and thus life-long surveillance cystoscopy is recommended in all patients undergoing TMT [64-66].

\section{THE ROLE OF TURBT IN THE MANAGEMENT OF DISEASE RECURRENCE FOLLOWING TMT}

\section{NMIBC recurrence}

Bladder cancer recurrence in patients who experience an initial complete response to TMT varies from $24-43 \%$, with the majority of reported series demonstrating a median time to local recurrence of $<2$ years [24, 28, 67-71]. Patients experiencing Ta NMIBC recurrence may be managed with repeat TURBT [24, 66]. Institution of intravesical BCG may provide further therapeutic benefit, however, the efficacy of this modality in the setting of TMT recurrence is not well defined $[24,66]$. Patients with T1 recurrence should be strongly considered for salvage cystectomy, although TURBT and intravesical BCG remains an option. Future Ta recurrences can be managed with repeat TURBT, while salvage RC may be necessary in those cases in which TURBT is not felt to be an appropriate option secondary to high burden of disease, difficult tumor location, or recurrent high-risk NMIBC. Patients experiencing NMIBC recurrence have a significantly increased risk of future TMT failure, and 19-45\% of these patients will eventually require salvage $\mathrm{RC}[8,20,33,66$, $68,72]$. While patients with NMIBC recurrence are more likely to eventually require salvage $\mathrm{RC}$, they appear to have a CSS similar to those without NMIBC recurrence $[66,68]$.

\section{$M I B C$ recurrence and treatment failure}

Following complete response to TMT, evidence of recurrent MIBC at any point constitutes TMT failure and necessitates immediate salvage $\mathrm{RC}$ in all patients deemed medically fit to undergo operative intervention. Of those who experience recurrence of disease, 11-19\% will be found to have MIBC [14, $16,19,24,28,67-70]$. Despite a delay to surgical treatment, TMT complete responders receiving salvage RC have demonstrated 5-year post-RC CSS rates similar to those undergoing primary $\mathrm{RC}$ [28]. Overall rates of salvage $\mathrm{RC}$, consisting of both immediate non-responders and initial complete responders ranges from $25-30 \%[14,16,31,32,61,68,70$, 72-78]. There is typically no role for TURBT in the management of MIBC recurrence with curative intent.

\section{QUALITY OF LIFE CONSIDERATIONS}

An improved overall quality of life represents an assumed benefit and primary driving force for many patients electing to undergo bladder preservation therapy with TMT. Despite the morbidity associated with RC, multiple studies using several different validated instruments have shown good overall health-related quality of life following surgery regardless of the type of urinary diversion chosen [79-84]. However, both urinary incontinence and erectile dysfunction can be significant post-operative issues. Gilbert et al reported that $54 \%$ of patients undergoing $\mathrm{RC}$ with neobladder experienced nightly urinary leakage, and the impact of incontinence on quality of life for those undergoing $\mathrm{RC}$ with neobladder diversion was significantly greater than controls not treated with RC [80]. Additionally, sexual function was noted to be significantly lower and more bothersome in both RC groups (neobladder and ileal conduit) when compared to non-operative controls.

Data pertaining to quality of life and bladder function following TMT is currently limited. In one analysis of 32 long-term TMT survivors, urodynamics revealed no abnormalities in 24 patients (75\%) and decreased compliance in 7 patients (22\%) [85]. Urinary complaints included symptoms of abnormal flow $(6 \%)$, urinary urgency (15\%), and incontinence (19\%); however, distress from these symptoms was only half as common as their prevalence. In terms of sexual function, $54 \%$ of men were capable of achieving an erection satisfactory for sexual intercourse and only $8 \%$ reported dissatisfaction with their sexual function. While overall global health-related quality of life was high amongst this cohort, no direct comparison of TMT and RC has been performed to date.

\section{CONCLUSIONS}

TMT is a viable alternative to $\mathrm{RC}$ in select patients with MIBC who desire bladder preservation 
or cannot tolerate major surgery. Careful selection of patients with a unifocal tumor and absence of hydronephrosis or adverse pathologic features offer the best chance for a durable response. Performing a complete TURBT as part of TMT is paramount to maximizing cancer control and long-term bladder preservation rates. Additionally, TURBT plays a critical role in assessing TMT response and in the management of NMIBC recurrences while on TMT protocols. Advances in tumor profiling, predictive biomarkers, dosing, delivery of radiation therapy, and use of systemic immunotherapy may continue to expand the pool of patients eligible for TMT and further improve outcomes.

\section{DISCLOSURES}

None.

\section{REFERENCES}

[1] Stenzl A, Cowan NC, De Santis M, Kuczyk MA, Merseburger AS, Ribal MJ, et al. Treatment of muscle-invasive and metastatic bladder cancer: Update of the EAU guidelines. European Urology 2011;59(6):1009-18. PubMed PMID: 21454009. Epub 2011/04/02. eng.

[2] Gakis G, Efstathiou J, Lerner SP, Cookson MS, Keegan KA, Guru KA, et al. ICUD-EAU International Consultation on Bladder Cancer 2012: Radical cystectomy and bladder preservation for muscle-invasive urothelial carcinoma of the bladder. European Urology 2013;63(1):45-57. PubMed PMID: 22917985. Epub 2012/08/25. eng.

[3] Shabsigh A, Korets R, Vora KC, Brooks CM, Cronin AM, Savage C, et al. Defining early morbidity of radical cystectomy for patients with bladder cancer using a standardized reporting methodology. European Urology 2009;55(1):16474. PubMed PMID: 18675501. Epub 2008/08/05. eng.

[4] Donat SM, Shabsigh A, Savage C, Cronin AM, Bochner BH, Dalbagni G, et al. Potential impact of postoperative early complications on the timing of adjuvant chemotherapy in patients undergoing radical cystectomy: A high-volume tertiary cancer center experience. European Urology 2009;55(1):177-85. PubMed PMID: 18640770. Epub 2008/07/22. eng.

[5] Gandaglia G, Varda B, Sood A, Pucheril D, Konijeti R, Sammon JD, et al. Short-term perioperative outcomes of patients treated with radical cystectomy for bladder cancer included in the National Surgical Quality Improvement Program (NSQIP) database. Canadian Urological Association Journal=Journal de l'Association Des Urologues Du Canada 2014;8(9-10):E681-7. PubMed PMID: 25408807. Pubmed Central PMCID: 4216299. Epub 2014/11/20. eng.

[6] Chen RC, Shipley WU, Efstathiou JA, Zietman AL. Trimodality bladder preservation therapy for muscle-invasive bladder cancer. Journal of the National Comprehensive Cancer Network: JNCCN 2013 ;11(8):952-60. PubMed PMID: 23946174.

[7] Barnes RW, Dick AL, Hadley HL, Johnston OL. Survival following transurethral resection of bladder carcinoma.
Cancer Research 1977;37(8 Pt 2):2895-7. PubMed PMID: 872119. Epub 1977/08/01. eng.

[8] Herr HW. Transurethral resection of muscle-invasive bladder cancer: 10-year outcome. Journal of Clinical Oncology : Official Journal of the American Society of Clinical Oncology 2001;19(1):89-93. PubMed PMID: 11134199. Epub 2001/01/03. eng.

[9] Solsona E, Iborra I, Collado A, Rubio-Briones J, Casanova J, Calatrava A. Feasibility of radical transurethral resection as monotherapy for selected patients with muscle invasive bladder cancer. The Journal of Urology 2010;184(2):475-80. PubMed PMID: 20620402. Epub 2010/07/14. eng.

[10] Jenkins BJ, Caulfield MJ, Fowler CG, Badenoch DF, Tiptaft $\mathrm{RC}$, Paris AM, et al. Reappraisal of the role of radical radiotherapy and salvage cystectomy in the treatment of invasive (T2/T3) bladder cancer. British Journal of Urology 1988;62(4):343-6. PubMed PMID: 3191360. Epub 1988/10/01. eng.

[11] Pollack A, Zagars GZ. Radiotherapy for stage T3b transitional cell carcinoma of the bladder. Seminars in Urologic Oncology 1996;14(2):86-95. PubMed PMID: 8734736. Epub 1996/05/01. eng

[12] Mameghan H, Fisher R, Mameghan J, Brook S. Analysis of failure following definitive radiotherapy for invasive transitional cell carcinoma of the bladder. International Journal of Radiation Oncology, Biology, Physics 1995;31(2):247-54. PubMed PMID: 7836076. Epub 1995/01/15. eng.

[13] Leibovici D, Kassouf W, Pisters LL, Pettaway CA, $\mathrm{Wu} \mathrm{X}$, Dinney $\mathrm{CP}$, et al. Organ preservation for muscle-invasive bladder cancer by transurethral resection. Urology 2007;70(3):473-6. PubMed PMID: 17905099. Epub 2007/10/02. eng.

[14] James ND, Hussain SA, Hall E, Jenkins P, Tremlett J, Rawlings $\mathrm{C}$, et al. Radiotherapy with or without chemotherapy in muscle-invasive bladder cancer. The New England Journal of Medicine 2012 ;366(16):1477-88. PubMed PMID: 22512481. Epub 2012/04/20. eng.

[15] Tunio MA, Hashmi A, Qayyum A, Mohsin R, Zaeem A Whole-pelvis or bladder-only chemoradiation for lymph node-negative invasive bladder cancer: Single-institution experience. International Journal of Radiation Oncology, Biology, Physics 2012;82(3):e457-62. PubMed PMID: 21945107. Epub 2011/09/29. eng.

[16] Shipley WU, Winter KA, Kaufman DS, Lee WR, Heney NM, Tester WR, et al. Phase III trial of neoadjuvant chemotherapy in patients with invasive bladder cancer treated with selective bladder preservation by combined radiation therapy and chemotherapy: Initial results of Radiation Therapy Oncology Group 89-03. Journal of Clinical Oncology: Official Journal of the American Society of Clinical Oncology 1998;16(11):3576-83. PubMed PMID: 9817278. Epub 1998/11/17. eng.

[17] Housset M, Maulard C, Chretien Y, Dufour B, Delanian $\mathrm{S}$, Huart $\mathrm{J}$, et al. Combined radiation and chemotherapy for invasive transitional-cell carcinoma of the bladder: A prospective study. Journal of Clinical Oncology: Official Journal of the American Society of Clinical Oncology 1993;11(11):2150-7. PubMed PMID: 8229129. Epub 1993/11/01. eng.

[18] Mak RH, Hunt D, Shipley WU, Efstathiou JA, Tester WJ, Hagan MP, et al. Long-term outcomes in patients with muscle-invasive bladder cancer after selective bladderpreserving combined-modality therapy: A pooled analysis of Radiation Therapy Oncology Group protocols 8802, 
8903, 9506, 9706, 9906, and 0233. Journal of Clinical Oncology: Official Journal of the American Society of Clinical Oncology 2014;32(34):3801-9. PubMed PMID: 25366678. Pubmed Central PMCID: 4239302.

[19] Efstathiou JA, Spiegel DY, Shipley WU, Heney NM, Kaufman DS, Niemierko A, et al. Long-term outcomes of selective bladder preservation by combined-modality therapy for invasive bladder cancer: The MGH experience. European Urology 2012;61(4):705-11. PubMed PMID: 22101114. Epub 2011/11/22. eng.

[20] Danesi DT, Arcangeli G, Cruciani E, Altavista P, Mecozzi A, Saracino B, et al. Conservative treatment of invasive bladder carcinoma by transurethral resection, protracted intravenous infusion chemotherapy, and hyperfractionated radiotherapy: Long term results. Cancer 2004;101(11):2540-8. PubMed PMID: 15481058. Epub 2004/10/14. eng.

[21] Perdona S, Autorino R, Damiano R, De Sio M, Morrica $\mathrm{B}$, Gallo L, et al. Bladder-sparing, combined-modality approach for muscle-invasive bladder cancer: A multiinstitutional, long-term experience. Cancer 2008;112(1):7583. PubMed PMID: 18008364. Epub 2007/11/17. eng.

[22] Sabaa MA, El-Gamal OM, Abo-Elenen M, Khanam A. Combined modality treatment with bladder preservation for muscle invasive bladder cancer. Urologic Oncology 2010;28(1):14-20. PubMed PMID: 18818110. Epub 2008/09/27. eng.

[23] Arias F, Dominguez MA, Martinez E, Illarramendi JJ, Miquelez S, Pascual I, et al. Chemoradiotherapy for muscle invading bladder carcinoma. Final report of a single institutional organ-sparing program. International Journal of Radiation Oncology, Biology, Physics 2000;47(2):373-8. PubMed PMID: 10802362. Epub 2000/05/10. eng.

[24] Kachnic LA, Kaufman DS, Heney NM, Althausen AF, Griffin PP, Zietman AL, et al. Bladder preservation by combined modality therapy for invasive bladder cancer. Journal of Clinical Oncology: Official Journal of the American Society of Clinical Oncology 1997;15(3):1022-9. PubMed PMID: 9060542. Epub 1997/03/01. eng.

[25] Tester W, Caplan R, Heaney J, Venner P, Whittington $\mathrm{R}$, Byhardt $\mathrm{R}$, et al. Neoadjuvant combined modality program with selective organ preservation for invasive bladder cancer: Results of Radiation Therapy Oncology Group phase II trial 8802. Journal of Clinical Oncology : Official Journal of the American Society of Clinical Oncology 1996;14(1):119-26. PubMed PMID: 8558186. Epub 1996/01/01. eng.

[26] Fellin G, Graffer U, Bolner A, Ambrosini G, Caffo O, Luciani L. Combined chemotherapy and radiation with selective organ preservation for muscle-invasive bladder carcinoma. A single-institution phase II study. British Journal of Urology 1997;80(1):44-9. PubMed PMID: 9240179. Epub 1997/07/01. eng.

[27] Cobo M, Delgado R, Gil S, Herruzo I, Baena V, Carabante $\mathrm{F}$, et al. Conservative treatment with transurethral resection, neoadjuvant chemotherapy followed by radiochemotherapy in stage T2-3 transitional bladder cancer. Clinical \& Translational Oncology : Official Publication of the Federation of Spanish Oncology Societies and of the National Cancer Institute of Mexico 2006;8(12):903-11. PubMed PMID: 17169764. Epub 2006/12/16. eng.

[28] Rodel C, Grabenbauer GG, Kuhn R, Papadopoulos T, Dunst J, Meyer M, et al. Combined-modality treatment and selective organ preservation in invasive bladder cancer: Long-term results. Journal of Clinical Oncology : Official Journal of the American Society of Clinical Oncology
2002;20(14):3061-71. PubMed PMID: 12118019. Epub 2002/07/16. eng.

[29] Rodel C, Weiss C, Sauer R. Trimodality treatment and selective organ preservation for bladder cancer. Journal of Clinical Oncology: Official Journal of the American Society of Clinical Oncology 2006;24(35):5536-44. PubMed PMID: 17158539. Epub 2006/12/13. eng.

[30] Krause FS, Walter B, Ott OJ, Haberle L, Weiss C, Rodel C, et al. 15-year survival rates after transurethral resection and radiochemotherapy or radiation in bladder cancer treatment. Anticancer Research 2011;31(3):985-90. PubMed PMID: 21498726. Epub 2011/04/19. eng.

[31] Zapatero A, Martin De Vidales C, Arellano R, Ibanez Y, Bocardo G, Perez M, et al. Long-term results of two prospective bladder-sparing trimodality approaches for invasive bladder cancer: Neoadjuvant chemotherapy and concurrent radio-chemotherapy. Urology 2012;80(5):105662. PubMed PMID: 22999456. Epub 2012/09/25. eng.

[32] Peyromaure M, Slama J, Beuzeboc P, Ponvert D, Debre B, Zerbib M. Concurrent chemoradiotherapy for clinical stage T2 bladder cancer: Report of a single institution. Urology 2004;63(1):73-7. PubMed PMID: 14751352. Epub 2004/01/31. eng.

[33] Shipley WU, Kaufman DS, Zehr E, Heney NM, Lane SC, Thakral HK, et al. Selective bladder preservation by combined modality protocol treatment: Long-term outcomes of 190 patients with invasive bladder cancer. Urology 2002;60(1):62-7; discussion 7-8. PubMed PMID: 12100923. Epub 2002/07/09. eng.

[34] Onozawa M, Miyanaga N, Hinotsu S, Miyazaki J, Oikawa T, Kimura T, et al. Analysis of Intravesical Recurrence After Bladder-preserving Therapy for Muscle-invasive Bladder Cancer. Japanese Journal of Clinical Oncology 2012;42(9):825-30. PubMed PMID: 22782963. Epub 2012/07/12. eng.

[35] Lin CC, Hsu CH, Cheng JC, Huang CY, Tsai YC, Hsu FM, et al. Induction cisplatin and fluorouracil-based chemotherapy followed by concurrent chemoradiation for muscle-invasive bladder cancer. International Journal of Radiation Oncology, Biology, Physics 2009;75(2):442-8. PubMed PMID: 19307067. Epub 2009/03/25. eng.

[36] Shipley WU, Rose MA, Perrone TL, Mannix CM, Heney NM, Prout GR, Jr. Full-dose irradiation for patients with invasive bladder carcinoma: Clinical and histological factors prognostic of improved survival. The Journal of Urology 1985;134(4):679-83. PubMed PMID: 4032570. Epub 1985/10/01. eng.

[37] Tilki D, Shariat SF, Lotan Y, Rink M, Karakiewicz PI, Schoenberg MP, et al. Lymphovascular invasion is independently associated with bladder cancer recurrence and survival in patients with final stage $\mathrm{T} 1$ disease and negative lymph nodes after radical cystectomy. BJU International 2013;111(8):1215-21. PubMed PMID: 23181623. Epub 2012/11/28. eng.

[38] Watts KL, Ristau BT, Yamase HT, Taylor JA, 3rd. Prognostic implications of lymph node involvement in bladder cancer: Are we understaging using current methods? BJU International 2011;108(4):484-92. PubMed PMID: 21794064. Epub 2011/07/29. eng.

[39] Clark PE, Agarwal N, Biagioli MC, Eisenberger MA, Greenberg RE, Herr HW, et al. Bladder cancer. Journal of the National Comprehensive Cancer Network : JNCCN 2013;11(4):446-75. PubMed PMID: 23584347.

[40] Brausi M, Witjes JA, Lamm D, Persad R, Palou J, Colombel $\mathrm{M}$, et al. A review of current guidelines and best prac- 
tice recommendations for the management of nonmuscle invasive bladder cancer by the International Bladder Cancer Group. The Journal of Urology 2011;186(6):2158-67. PubMed PMID: 22014799.

[41] Burger M, Oosterlinck W, Konety B, Chang S, Gudjonsson $\mathrm{S}$, Pruthi R, et al. ICUD-EAU International Consultation on Bladder Cancer 2012: Non-muscle-invasive urothelial carcinoma of the bladder. European Urology 2013;63(1):3644. PubMed PMID: 22981672.

[42] National Comprehensive Cancer Network Clinical Practice Guidelines in Oncology. Bladder Cancer. Version 2.2016. Available at www.nccn.org. Accessed July 31.

[43] Milowsky MI, Rumble RB, Lee CT. Guideline on Muscle-Invasive and Metastatic Bladder Cancer (European Association of Urology Guideline): American Society of Clinical Oncology Clinical Practice Guideline Endorsement Summary. Journal of Oncology Practice / American Society of Clinical Oncology 2016;12(6):588-90. PubMed PMID: 27221997.

[44] Milowsky MI, Rumble RB, Booth CM, Gilligan T, Eapen LJ, Hauke RJ, et al. Guideline on Muscle-Invasive and Metastatic Bladder Cancer (European Association of Urology Guideline): American Society of Clinical Oncology Clinical Practice Guideline Endorsement. Journal of Clinical Oncology : Official Journal of the American Society of Clinical Oncology 2016;34(16):1945-52. PubMed PMID: 27001593.

[45] Herr HW. The value of a second transurethral resection in evaluating patients with bladder tumors. The Journal of Urology 1999;162(1):74-6. PubMed PMID: 10379743.

[46] Adiyat KT, Katkoori D, Soloway CT, De los Santos R, Manoharan M, Soloway MS. Complete transurethral resection of bladder tumor: Are the guidelines being followed? Urology 2010;75(2):365-7. PubMed PMID: 19963238.

[47] Richards KA, Smith ND, Steinberg GD. The importance of transurethral resection of bladder tumor in the management of nonmuscle invasive bladder cancer: A systematic review of novel technologies. The Journal of Urology 2014;191(6):1655-64. PubMed PMID: 24518761.

[48] Mariappan P, Finney SM, Head E, Somani BK, Zachou A, Smith G, et al. Good quality white-light transurethral resection of bladder tumours (GQ-WLTURBT) with experienced surgeons performing complete resections and obtaining detrusor muscle reduces early recurrence in new nonmuscle-invasive bladder cancer: Validation across time and place and recommendation for benchmarking. BJU International 2012;109(11):1666-73. PubMed PMID: 22044434.

[49] Lee SH, Jeong CW, Lee HJ, Yoon MH, Kim WM. Ultrasound guided obturator nerve block: A single interfascial injection technique. Journal of Anesthesia 2011;25(6):9236. PubMed PMID: 21918855.

[50] Khorrami M, Hadi M, Javid A, Izadpahani MH, Mohammadi Sichani M, Zargham M, et al. A comparison between blind and nerve stimulation guided obturator nerve block in transurethral resection of bladder tumor. Journal of Endourology / Endourological Society 2012;26(10):131922. PubMed PMID: 22658168.

[51] Wolf JS, Jr., Bennett CJ, Dmochowski RR, Hollenbeck BK, Pearle MS, Schaeffer AJ, et al. Best practice policy statement on urologic surgery antimicrobial prophylaxis. The Journal of Urology 2008;179(4):1379-90. PubMed PMID: 18280509 .

[52] Pan D, Soloway MS. The importance of transurethral resection in managing patients with urothelial cancer in the bladder: Proposal for a transurethral resection of bladder tumor checklist. European Urology 2012;61(6):1199-203. PubMed PMID: 22464897.

[53] Venkatramani V, Panda A, Manojkumar R, Kekre NS. Monopolar versus bipolar transurethral resection of bladder tumors: A single center, parallel arm, randomized, controlled trial. The Journal of Urology 2014;191(6):1703-7. PubMed PMID: 24333244.

[54] Wang DS, Bird VG, Leonard VY, Plumb SJ, Konety $\mathrm{B}$, Williams RD, et al. Use of bipolar energy for transurethral resection of bladder tumors: Pathologic considerations. Journal of Endourology / Endourological Society 2004;18(6):578-82. PubMed PMID: 15333227.

[55] Nieder AM, Manoharan M. The role of the surgeon and transurethral resection in the treatment of superficial bladder cancer. The Scientific World Journal 2006;6:2626-31. PubMed PMID: 17619740.

[56] Gakis G, Fahmy O. Systematic Review and Meta-Analysis on the Impact of Hexaminolevulinate- Versus White-Light Guided Transurethral Bladder Tumor Resection on Progression in Non-Muscle Invasive Bladder Cancer. Bladder Cancer 2016;2(3):293-300. PubMed PMID: 27500197. Pubmed Central PMCID: 4969683.

[57] Jichlinski P, Leisinger HJ. Fluorescence cystoscopy in the management of bladder cancer: A help for the urologist! Urologia Internationalis 2005;74(2):97-101. PubMed PMID: 15756058.

[58] Burger M, Grossman HB, Droller M, Schmidbauer J, Hermann G, Dragoescu O, et al. Photodynamic diagnosis of non-muscle-invasive bladder cancer with hexaminolevulinate cystoscopy: A meta-analysis of detection and recurrence based on raw data. European Urology 2013;64(5):846-54. PubMed PMID: 23602406.

[59] Schumacher MC, Holmang S, Davidsson T, Friedrich B, Pedersen J, Wiklund NP. Transurethral resection of nonmuscle-invasive bladder transitional cell cancers with or without 5-aminolevulinic Acid under visible and fluorescent light: Results of a prospective, randomised, multicentre study. European Urology 2010;57(2):293-9. PubMed PMID: 19913351.

[60] Pollack A, Zagars GK, Swanson DA. Muscle-invasive bladder cancer treated with external beam radiotherapy: Prognostic factors. International Journal of Radiation Oncology, Biology, Physics 1994;30(2):267-77. PubMed PMID: 7928456. Epub 1994/09/30. eng.

[61] Kragelj B, Zaletel-Kragelj L, Sedmak B, Cufer T, Cervek J. Phase II study of radiochemotherapy with vinblastine in invasive bladder cancer. Radiotherapy and Oncology: Journal of the European Society for Therapeutic Radiology and Oncology 2005;75(1):44-7. PubMed PMID: 15878100. Epub 2005/05/10. eng.

[62] Fung CY, Shipley WU, Young RH, Griffin PP, Convery KM, Kaufman DS, et al. Prognostic factors in invasive bladder carcinoma in a prospective trial of preoperative adjuvant chemotherapy and radiotherapy. Journal of Clinical Oncology: Official Journal of the American Society of Clinical Oncology 1991;9(9):1533-42. PubMed PMID: 1875217.

[63] Smith ZL, Christodouleas JP, Keefe SM, Malkowicz SB, Guzzo TJ. Bladder preservation in the treatment of muscleinvasive bladder cancer (MIBC): A review of the literature and a practical approach to therapy. BJU International 2013;112(1):13-25. PubMed PMID: 23356411.

[64] Herr HW. Tumour progression and survival in patients with T1G3 bladder tumours: 15-year outcome. British Journal of Urology 1997 ;80(5):762-5. PubMed PMID: 9393299. Epub 1997/12/11. eng. 
[65] Weiss C, Wittlinger M, Engehausen DG, Krause FS, Ott OJ, Dunst J, et al. Management of superficial recurrences in an irradiated bladder after combined-modality organ-preserving therapy. International Journal of Radiation Oncology, Biology, Physics 2008;70(5):1502-6. PubMed PMID: 17935905. Epub 2007/10/16. eng.

[66] Zietman AL, Grocela J, Zehr E, Kaufman DS, Young RH, Althausen AF, et al. Selective bladder conservation using transurethral resection, chemotherapy, and radiation: Management and consequences of $\mathrm{Ta}, \mathrm{T} 1$, and Tis recurrence within the retained bladder. Urology 2001;58(3):380-5. PubMed PMID: 11549485. Epub 2001/09/11. eng.

[67] Hagan MP, Winter KA, Kaufman DS, Wajsman Z, Zietman AL, Heney NM, et al. RTOG 97-06: Initial report of a phase I-II trial of selective bladder conservation using TURBT, twice-daily accelerated irradiation sensitized with cisplatin, and adjuvant MCV combination chemotherapy. International Journal of Radiation Oncology, Biology, Physics 2003;57(3):665-72. PubMed PMID: 14529770. Epub 2003/10/08. eng.

[68] Weiss C, Engehausen DG, Krause FS, Papadopoulos T, Dunst J, Sauer R, et al. Radiochemotherapy with cisplatin and 5-fluorouracil after transurethral surgery in patients with bladder cancer. International Journal of Radiation Oncology, Biology, Physics 2007;68(4):1072-80. PubMed PMID: 17467193. Epub 2007/05/01. eng.

[69] Kaufman DS, Winter KA, Shipley WU, Heney NM, Wallace HJ, 3rd, Toonkel LM, et al. Phase I-II RTOG study (99-06) of patients with muscle-invasive bladder cancer undergoing transurethral surgery, paclitaxel, cisplatin, and twice-daily radiotherapy followed by selective bladder preservation or radical cystectomy and adjuvant chemotherapy. Urology 2009;73(4):833-7. PubMed PMID: 19100600. Epub 2008/12/23. eng.

[70] Gogna NK, Matthews JH, Turner SL, Mameghan H, Duchesne GM, Spry N, et al. Efficacy and tolerability of concurrent weekly low dose cisplatin during radiation treatment of localised muscle invasive bladder transitional cell carcinoma: A report of two sequential Phase II studies from the Trans Tasman Radiation Oncology Group. Radiotherapy and Oncology: Journal of the European Society for Therapeutic Radiology and Oncology 2006;81(1):917. PubMed PMID: 17011058. Epub 2006/10/03. eng.

[71] Madersbacher S, Hochreiter W, Burkhard F, Thalmann GN, Danuser H, Markwalder R, et al. Radical cystectomy for bladder cancer today-a homogeneous series without neoadjuvant therapy. Journal of Clinical Oncology: Official Journal of the American Society of Clinical Oncology 2003;21(4):690-6. PubMed PMID: 12586807. Epub 2003/02/15. eng.

[72] Choudhury A, Swindell R, Logue JP, Elliott PA, Livsey JE, Wise M, et al. Phase II study of conformal hypofractionated radiotherapy with concurrent gemcitabine in muscle-invasive bladder cancer. Journal of Clinical Oncology: Official Journal of the American Society of Clinical Oncology 2011;29(6):733-8. PubMed PMID: 21205754. Epub 2011/01/06. eng.

[73] Lagrange JL, Bascoul-Mollevi C, Geoffrois L, Beckendorf V, Ferrero JM, Joly F, et al. Quality of life assessment after concurrent chemoradiation for invasive bladder cancer: Results of a multicenter prospective study (GETUG 97-015). International Journal of Radiation Oncology, Biology, Physics 2011;79(1):172-8. PubMed PMID: 20385453. Epub 2010/04/14. eng.
[74] Aboziada MA, Hamza HM, Abdlrahem AM. Initial results of bladder preserving approach by chemo-radiotherapy in patients with muscle invading transitional cell carcinoma. Journal of the Egyptian National Cancer Institute 2009;21(2):167-74. PubMed PMID: 21057568. Epub 2009/06/01. eng.

[75] Tester W, Porter A, Asbell S, Coughlin C, Heaney J, Krall $\mathrm{J}$, et al. Combined modality program with possible organ preservation for invasive bladder carcinoma: Results of RTOG protocol 85-12. International Journal of Radiation Oncology, Biology, Physics 1993;25(5):783-90. PubMed PMID: 8478228. Epub 1993/04/02. eng.

[76] Russell KJ, Boileau MA, Higano C, Collins C, Russell $\mathrm{AH}, \mathrm{Koh} \mathrm{W}$, et al. Combined 5-fluorouracil and irradiation for transitional cell carcinoma of the urinary bladder. International Journal of Radiation Oncology, Biology, Physics 1990;19(3):693-9. PubMed PMID: 2211217. Epub 1990/09/01. eng.

[77] Hussain SA, Stocken DD, Peake DR, Glaholm JG, Zarkar A, Wallace DM, et al. Long-term results of a phase II study of synchronous chemoradiotherapy in advanced muscle invasive bladder cancer. British Journal of Cancer 2004;90(11):2106-11. PubMed PMID: 15150587. Pubmed Central PMCID: 2409507. Epub 2004/05/20. eng.

[78] Kaufman DS, Winter KA, Shipley WU, Heney NM, Chetner MP, Souhami L, et al. The initial results in muscleinvading bladder cancer of RTOG 95-06: Phase I/II trial of transurethral surgery plus radiation therapy with concurrent cisplatin and 5-fluorouracil followed by selective bladder preservation or cystectomy depending on the initial response. The Oncologist 2000;5(6):471-6. PubMed PMID: 11110598. Epub 2000/12/08. eng.

[79] Allareddy V, Kennedy J, West MM, Konety BR. Quality of life in long-term survivors of bladder cancer. Cancer 2006;106(11):2355-62. PubMed PMID: 16649218.

[80] Gilbert SM, Wood DP, Dunn RL, Weizer AZ, Lee CT, Montie JE, et al. Measuring health-related quality of life outcomes in bladder cancer patients using the Bladder Cancer Index (BCI). Cancer 2007;109(9):1756-62. PubMed PMID: 17366596.

[81] Hart S, Skinner EC, Meyerowitz BE, Boyd S, Lieskovsky G, Skinner DG. Quality of life after radical cystectomy for bladder cancer in patients with an ileal conduit, cutaneous or urethral kock pouch. The Journal of Urology 1999;162(1):77-81. PubMed PMID: 10379744.

[82] Mottet N, Castagnola C, Rischmann P, Deixonne M, Guyot M, Coloby P, et al. [Quality of life after cystectomy: French national survey conducted by the French Association of Urology (AFU), the French Federation of Stoma Patients (FSF) and the French Association of Enterostomy Patients (AFET) in patients with ileal conduit urinary diversion or orthotopic neobladder]. Progres en urologie : Journal de 1'Association francaise d'urologie et de la Societe francaise d'urologie 2008;18(5):292-8. PubMed PMID: 18538274. Qualite de vie apres cystectomie: Enquete nationale de l'Association francaise d'urologie (AFU), la Federation des stomises de France (FSF) et de l'Association francaise des enterostomatherapeutes (AFET) chez des patients ayant eu une derivation urinaire cutanee non continente ou un remplacement vesical orthotopique.

[83] Henningsohn L, Steven K, Kallestrup EB, Steineck G. Distressful symptoms and well-being after radical cystectomy and orthotopic bladder substitution compared with a matched control population. The Journal of Urology 
2002;168(1):168-74; discussion 74-5. PubMed PMID: 1205 0515.

[84] Anderson CB, Feurer ID, Large MC, Steinberg GD, Barocas DA, Cookson MS, et al. Psychometric characteristics of a condition-specific, health-related quality-of-life survey: The FACT-Vanderbilt Cystectomy Index. Urology 2012;80(1):77-83. PubMed PMID: 22608798.
[85] Zietman AL, Sacco D, Skowronski U, Gomery P, Kaufman DS, Clark JA, et al. Organ conservation in invasive bladder cancer by transurethral resection, chemotherapy and radiation: Results of a urodynamic and quality of life study on long-term survivors. J Urology 2003;170(5):17726. PubMed PMID: WOS:000185858400015. English. 